\title{
Arsenic Geochemistry in Groundwater System
}

\author{
Dionisios Panagiotaras ${ }^{1}$, George Panagopoulos², \\ Dimitrios Papoulis ${ }^{3}$ and Pavlos Avramidis ${ }^{4}$ \\ ${ }^{1}$ Department of Mechanical Engineering, Laboratory of Chemistry, Technological \\ Educational Institute (T.E.I.) of Patras, Patras \\ ${ }^{2}$ Department of Mechanical and Water Resources Engineering, Technological Educational \\ Institute (T.E.I.) of Messolonghi, Nea Ktiria, Messolonghi \\ ${ }^{3}$ Department of Geology, University of Patras, Patras \\ ${ }^{4}$ Technological Educational Institute (T.E.I.) of Mesolonghi, Laboratory of Geology for \\ Aquatic Systems, Nea Ktiria Mesolonghi \\ 1,2,3,4Greece
}

\section{Introduction}

Enormous population numbers from the global setting are known to have been affected by the adverse effects of arsenic. Further, soil and groundwater reserves have been contaminated. This has created the need for remediation. Treatment of arsenic has proved to be a difficult task to accomplish diachronically since it changes valence states and reacts towards the formation of species with varying toxicity and mobility [1].

The Maximum Contaminant Level (MCL) that provides the measurement for arsenic in drinking water was recently reduced by the United States Environmental Protection Agency (EPA) from $0.050 \mathrm{mg} / 1$ to $0.010 \mathrm{mg} / 1$ [2].

In the majority of the countries, the background values of arsenic in groundwater are less than $10 \mathrm{mg} / \mathrm{l}$ and sometimes even lower (USA values from Welch et al., 2000 [3]; UK values from Edmunds et al., 1989 [4]).

Arsenic shows variations from $<0.5$ to $5000 \mathrm{mg} / \mathrm{l}$ under natural conditions. Oxidising (under conditions of high $\mathrm{pH}$ ) and reducing aquifers and areas affected by geothermal, mining and industrial activity provide a nurturing environment for high concentrations of Arsenic.

In the majority of the cases, natural sources have been found to contribute towards high level concentration of Arsenic. Meanwhile, mining activities result to high occurrence of arsenic locally. Furthermore, arsenic pollution increases at local levels due to industrial and agricultural activities.

Currently, there are reports on groundwater As problems from a magnitude of countries ranging from Argentina, Bangladesh, Chile, China, Hungary, India (West Bengal) to Mexico, Romania, Taiwan, Vietnam and many parts of the USA, particularly the southwest USA. The need for a rapid assessment of the situation in aquifers worldwide has been surfaced as a result of recent research discovery of As enrichment on a large scale $[1,2,5]$. 
Therefore, there is an imminent need from the side of the organisations that supply drinking water to provide new ways for treatment or to alter the existing treatment systems in order to meet the revised MCL. Relevant literature provides evidence on the fact that precipitation / co-precipitation is frequently used for purposes of treating arsenic-contaminated water. Furthermore, it is capable to treat influent arsenic concentrations in the revised MCL.

On the other hand, absorption and ion exchange for arsenic treatment is likely to be affected by characteristics and contaminants different to arsenic. Absorption and ion exchange appear to be used more often in cases where arsenic is the main and only contaminant to be subjected to treatment. This applies to smaller systems but also to larger systems as a polishing technology. The use of membrane filtering is less frequent due to the fact that it incurs higher costs and produces large residual volumes as compared to other technologies relative to the treatment of arsenic $[1,2,6]$.

This chapter provides information needed to help meet the challenges of arsenic behavior in groundwaters. Clays, carbonaceous materials, and oxides of iron, aluminum and manganese are components that may participate in rock/soil-water interactions leading to enrichment or depletion with respect to arsenic.

\section{Arsenic geochemistry}

In nature arsenic occurs in air, soil, water, rocks, plants, and animals. Natural activities such as volcanic eruption, rocks erosion and forest fires, can release arsenic to the environment. The major arsenic minerals occurring in nature are presented in table 1 [5].

\begin{tabular}{|c|c|c|}
\hline Mineral & Composition & Occurrence \\
\hline Native arsenic & As & Hydrothermal veins \\
\hline Niccolite & $\mathrm{NiAs}$ & Vein deposits and norites \\
\hline Realgar & $\mathrm{As}_{2} \mathrm{~S}_{2}$ & $\begin{array}{l}\text { Vein deposits, often associated with orpiment, clays } \\
\text { and limestones, also deposits from hot springs }\end{array}$ \\
\hline Orpiment & $\mathrm{As}_{2} \mathrm{~S}_{3}$ & $\begin{array}{l}\text { Hydrothermal veins, hot springs, volcanic } \\
\text { sublimation products }\end{array}$ \\
\hline Cobaltite & CoAsS & High temperature deposits, metamorphic rocks \\
\hline Arsenopyrite & FeAsS & $\begin{array}{l}\text { The most abundant As mineral, dominantly in } \\
\text { mineral veins }\end{array}$ \\
\hline Tennantite & $(\mathrm{Cu}, \mathrm{Fe})_{12} \mathrm{As}_{4} \mathrm{~S}_{13}$ & Hydrothermal veins \\
\hline Enargite & $\mathrm{Cu}_{3} \mathrm{AsS}_{4}$ & Hydrothermal veins \\
\hline Arsenolite & $\mathrm{As}_{2} \mathrm{O}_{3}$ & $\begin{array}{l}\text { Secondary mineral formed by oxidation of } \\
\text { arsenopyrite native arsenic and other As minerals }\end{array}$ \\
\hline Clauderite & $\mathrm{As}_{2} \mathrm{O}_{3}$ & $\begin{array}{l}\text { Secondary mineral formed by oxidation of realgar } \\
\text { arsenopyrite and other As minerals }\end{array}$ \\
\hline Scorodite & $\mathrm{FeAsO}_{4} \cdot 2 \mathrm{H}_{2} \mathrm{O}$ & Secondary mineral \\
\hline Anabergite & $(\mathrm{Ni}, \mathrm{Co})_{3}\left(\mathrm{AsO}_{4}\right)_{2} \cdot 8 \mathrm{H}_{2} \mathrm{O}$ & Secondary mineral \\
\hline Hoernesite & $\mathrm{Mg}_{3}\left(\mathrm{AsO}_{4}\right)_{2} \cdot 8 \mathrm{H}_{2} \mathrm{O}$ & Secondary mineral, smelter wastes \\
\hline Haematolite & $(\mathrm{Mn}, \mathrm{Mg})_{4} \mathrm{Al}\left(\mathrm{AsO}_{4}\right)(\mathrm{OH})_{8}$ & Secondary mineral \\
\hline Conichalcite & $\mathrm{CaCu}\left(\mathrm{AsO}_{4}\right)(\mathrm{OH})$ & Secondary mineral \\
\hline Pharmacosiderite & $\mathrm{Fe}_{3}\left(\mathrm{AsO}_{4}\right)_{2}(\mathrm{OH})_{3} \cdot 5 \mathrm{H}_{2} \mathrm{O}$ & $\begin{array}{l}\text { Oxidation product of arsenopyrite and other As } \\
\text { minerals }\end{array}$ \\
\hline
\end{tabular}

Table 1. Major arsenic minerals occurring in nature [5]. 
Anthropogenic activities such as farming, mining, uses of fossil fuels, pulp and paper production, cement manufacturing et.al., contributing as additional sources of arsenic in the environment [7].

Arsenic is generally distributed in more than 320 minerals [8], and it's commonly found in arsenopyrite (FeAsS) $[9 ; 10 ; 11]$, orpiment $\left(\mathrm{As}_{2} \mathrm{~S}_{3}\right)$, realgar $\left(\mathrm{As}_{2} \mathrm{~S}_{2}\right)$, and pyrite solid solutions $\left(\mathrm{FeS}_{2}\right)$ [12; 13]. Arsenic is also present in sedimentary environments mainly adsorbed by $\mathrm{Fe}(\mathrm{III})$ and $\mathrm{Mn}(\mathrm{IV})$ after weathering of sulfide minerals $[11 ; 14 ; 15 ; 16]$.

The major sources of arsenic in natural waters include arsenic minerals, together with a once widespread use of arsenic in pigments, insecticides and herbicides. About $70 \%$ of all arsenic uses are in pesticides [17].

Other important uses of arsenic and its compounds are in wood preservatives, glass manufacture, electronics, catalysts, alloys, feed additives and veterinary chemicals. Many studies document the adverse health effects in humans exposed to inorganic arsenic compounds [7], [18].

Arsenic can form both inorganic and organic compounds. It occurs with valence states of -3 , $0,+3$ and +5 , nevertheless, the valence states of -3 and 0 occur only rarely in nature. This arsenic chemistry discussion focuses on inorganic species of $\mathrm{As}(\mathrm{III})$ and $\mathrm{As}(\mathrm{V})$. Inorganic compounds of arsenic include halides, hydrides (e.g., arsine), acids, oxides, and sulfides [19].

Arsenic's toxicity and mobility has been proved to vary with its chemical form and state of valence. In sea water and surface water, arsenite and arsenate constitute the dominant species. In addition, it is in natural gas and shale oil that organic arsenic species can be found. Varying degrees of toxicity and solubility can be evidenced in chemical compounds that contain arsenic [20].

The mobilization of arsenic in groundwater is controlled by several reactions i.e. dissolution/precipitation, adsorption / co-precipitation, and reduction/oxidation. Furthermore, numerous processes have given a rise to the existing global account for high levels of arsenic in natural water: The weathering of sulfide minerals provides for the reductive dissolution of arsenic rich iron oxyhydroxides [14;15; 16; 21; 22; 23]; Arsenic-rich pyrite or arsenopyrite oxidative dissolution [10; 12; 13; 24]; Arsenic - bearing minerals that interact with water $[10 ; 23]$.

Iron oxyhydroxides constitute the most common cause for the widespread contamination from arsenic. This is due to the post effect that evidenced following the reaction of iron oxyhydroxides with organic carbon release arsenic into solution [25; 26]. The oxidation of sulphide minerals such as pyrite is a major source of arsenic. It has also been found to constitute the primary source in aquifers located in Wisconsin and Michigan [26; 27].

\section{Arsenic chemical reactions and speciation in water}

Arsenic is a metalloid listed in group $\mathrm{V}_{\mathrm{A}}$ of the periodic table. It exists in nature in the oxidation states +V (arsenate), +III (arsenite), 0 (arsenic) and -III (arsine). In aqueous systems, arsenic exhibits anionic behaviour. In case of oxygenated waters, arsenic acid predominates only at extremely low $\mathrm{pH}(<2)$. In the $\mathrm{pH}$ range of 2 to 11 , it is in the form of 
$\mathrm{H}_{2} \mathrm{AsO}_{4}{ }^{-}$and $\mathrm{HAsO}_{4}{ }^{2-}$. In mildly reduced conditions and low $\mathrm{pH}$ values, arsenious acid converted to $\mathrm{H}_{2} \mathrm{AsO}_{3}{ }^{-}$as the $\mathrm{pH}$ increases. When the $\mathrm{pH}$ exceeds $12 \mathrm{HAsO}_{3}{ }^{2-}$ does appear (Fig.1).



Fig. 1. Eh-pH diagram of aqueous arsenic species in water at $25^{\circ} \mathrm{C}$ and 1 bar total pressure [5].

In the presence of sulphide and in low $\mathrm{pH}$ conditions, $\mathrm{HAsS}_{2}$ can form, arsine derivatives and arsenic metal can occur under extreme reducing conditions [27, 28]. Figure 1 shows the speciation of arsenic under varying $\mathrm{pH}$ and redox conditions [5].

In different environmental conditions arsenic readily changes its valence state and chemical form. Some conditions that may affect arsenic valence and speciation are presented: $\mathrm{pH}$ - in the $\mathrm{pH}$ range of 4 to $10, \mathrm{As}(\mathrm{V})$ species are negatively charged in water, and the predominant $\mathrm{As}(\mathrm{III})$ species is neutral in charge; redox potential; the presence of complexing ions, such as ions of sulfur, iron, and calcium; microbial activity [29].

Adsorption-desorption reactions can also affect the mobility of arsenic in the environment. Geomaterials such as clays, carbonaceous materials, and oxides of iron, aluminum, and manganese are sediment components that may participate in adsorptive reactions with arsenic [29]. 
Studying the Mahomet aquifer, Illinois, U.S.A., Holms et al 2004 [30], constructed Eh-pH diagrams for arsenic speciation. The portion of the diagram that includes the $\mathrm{pH}$ and Oxidation-Reduction Potential (ORP) values of the Mahomet Aquifer was recalculated from Holms et al 2004 [30], for $14^{\circ} \mathrm{C}$, the approximate temperature of the aquifer (Figure 2). They used thermodynamic data for temperature adjustments from Nordstrom and Archer 2003 [31].

The diagonal lines separating the $\mathrm{As}(\mathrm{V})$ and $\mathrm{As}(\mathrm{III})$ species in Figure 2 were calculated as follows. The half-reaction for the reduction of $\mathrm{As}(\mathrm{V})$ to $\mathrm{As}(\mathrm{III})$ was given by equation 1 .

$$
\mathrm{H}_{3} \mathrm{AsO}_{4}+2 \mathrm{H}^{+}+2 \mathrm{e}^{-}=\mathrm{H}_{3} \mathrm{AsO}_{3}+\mathrm{H}_{2} \mathrm{O}
$$

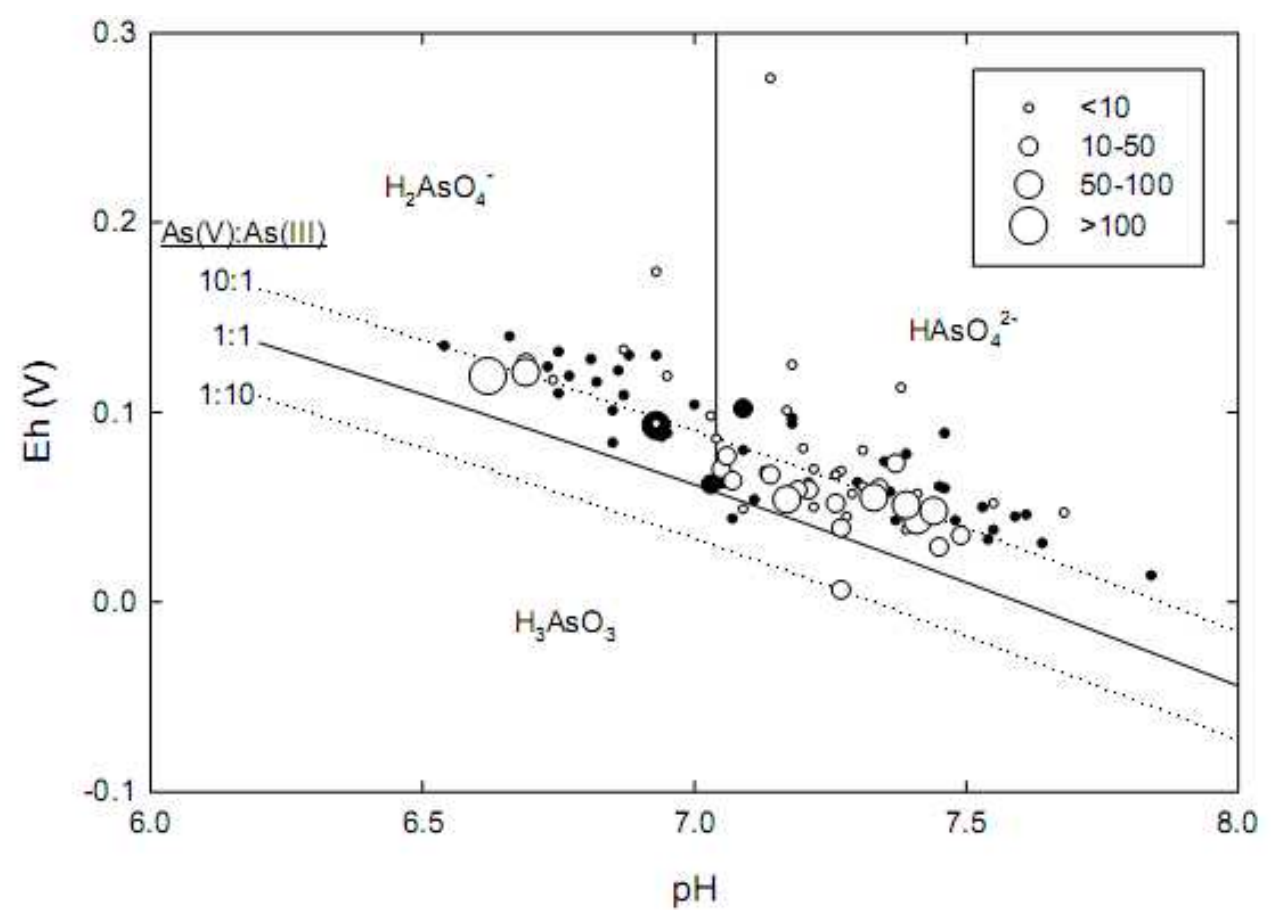

Fig. 2. Arsenic Eh-pH diagram, at $14{ }^{\circ} \mathrm{C}$. Size of symbols indicates dissolved As concentration in $\mu \mathrm{g} / \mathrm{L}$. Filled symbols Champaign County, open symbols Tazewell County. Dotted lines indicate shift in stability fields for different $\mathrm{As}(\mathrm{V})$ : As(III) ratios [30].

The Nernst equation (equation 2) relates the arsenic species concentrations at equilibrium.

$$
\mathrm{E}=\mathrm{E}^{0}+\mathrm{k}\left(\log _{10}\left(\frac{\mathrm{H}_{3} \mathrm{AsO}_{4}}{\mathrm{H}_{3} \mathrm{AsO}_{3}}\right)-2 \mathrm{pH}\right)
$$

In equation $2, \mathrm{E}^{0}$ and $\mathrm{k}$ are a constant and a collection of constants, respectively. In the $\mathrm{pH}$ range of the Mahomet Aquifer, $\mathrm{H}_{3} \mathrm{AsO}_{4}$ makes up a small fraction of the $\mathrm{As}(\mathrm{V})$, which is given by equation 3 [32]. 


$$
\mathrm{a}^{\mathrm{v}}=\frac{\left[\mathrm{H}_{3} \mathrm{AsO}_{4}\right]}{\mathrm{As}(\mathrm{V})}=\frac{1}{1+\mathrm{K}_{\mathrm{a} 1} 10^{\mathrm{pH}}+\mathrm{K}_{\mathrm{a} 1} \mathrm{~K}_{\mathrm{a} 2} 10^{2 \mathrm{pH}}+\mathrm{K}_{\mathrm{a} 1} \mathrm{~K}_{\mathrm{a} 2} \mathrm{~K}_{\mathrm{a} 3} 10^{3 \mathrm{pH}}}
$$

A similar equation can be derived for the fraction of $\mathrm{As}(\mathrm{III})$ in the $\mathrm{H}_{3} \mathrm{AsO}_{3}$ form ( $\mathrm{a}^{\mathrm{III}}$ ). Essentially all of the $\mathrm{As}(\mathrm{III})$ is in the $\mathrm{H}_{3} \mathrm{AsO}_{3}$ form. Substituting equation 3 into equation 2 gives equation 4 , which relates the equilibrium redox potential to the $\mathrm{pH}$ and concentrations of $\mathrm{As}(\mathrm{V})$ and $\mathrm{As}(\mathrm{III})$ (measured quantities [30; 32]).

$$
\mathrm{E}=\mathrm{E}^{0}+\mathrm{k}\left(\log _{10}\left(\frac{\mathrm{As}(\mathrm{V}) \mathrm{a}^{\mathrm{v}}}{\mathrm{As}(\mathrm{III}) \mathrm{a}^{\mathrm{III}}}\right)-2 \mathrm{pH}\right)
$$

The lines labeled 1:1, 10:1, and 1:10 in Figure 2 are for the different ratios of $\mathrm{As}(\mathrm{V})$ to $\mathrm{As}(\mathrm{III})$ used in equation 4 . The measured $\mathrm{pH}$ and ORP values, the points in Figure 2, plot in areas for which both $\mathrm{As}(\mathrm{III})$ and $\mathrm{As}(\mathrm{V})$ should be detectable and, indeed, both species were detectable in most samples [30; 32]. However, most of the points in Figure 2 lie in the $\mathrm{As}(\mathrm{V})$ field, the area in which $\mathrm{As}(\mathrm{V})$ makes up more than $50 \%$ of the total arsenic, whereas As(III) made up at least $85 \%$ of the arsenic in most of the samples analyzed in the present work [30; 32].

Other researchers have also found that their $\mathrm{pH}-\mathrm{ORP}$ data plot completely in the As(V) field [33; 34; 35; 36; 37; 38]. Smedley 1996 [37], reported groundwater analyses for which As(III) made up 3-39\% of the total arsenic, the ORP values were $221-469 \mathrm{mV}$, and the $\mathrm{pH}$ values were between 5.4 and 7.2. Although many of these data would be off the top of the scale of Figure 2, both arsenic species were detectable [30,37].

The only As(III) species considered in equation 4 are $\mathrm{H}_{3} \mathrm{AsO}_{3}$ and $\mathrm{H}_{2} \mathrm{AsO}_{3}$, , so the value of (aII) was close to 1.0 for all measured $\mathrm{pH}$ values. However, there is evidence for complexation of $\mathrm{As}(\mathrm{III})$ by carbonate ions [39; 40]. The alkalinity values in the Mahomet Aquifer are fairly high $(10 \mathrm{mmol} / \mathrm{l})$, so if the $\mathrm{As}(\mathrm{III})-\mathrm{HCO}_{3}{ }^{-}$stability constants are large enough, (aII) could be significantly less than 1.0. An aIII value of 0.1 would shift the As(III)$\mathrm{As}(\mathrm{V})$ boundary up approximately $30 \mathrm{mV}$ and many more points would plot in the As(III) field [30; 32].

The shallow aquifers in Bangladesh and eastern India have attracted the focus of an array of studies regarding the source and fate arsenic in groundwater. The pollution of groundwater derives from organic-rich deltaic sediments. These sediments show highest concentrations in deeper and more reduced sections of the aquifers. As a result, different chemical correlations with arsenic have been reported by many investigators. Arsenic and iron have been found to be associated in the solid phase, and sometimes in solution but sometimes not $[15 ; 16 ; 41 ; 42 ; 43]$.

The arsenic, either adsorbed to or co-precipitated with $\mathrm{FeOOH}$, is released into solution. The adsorption of metal ions onto the surface of the metal oxides-hydroxides can be described by the equation 5, introduced by Stumm and Morgan 1996 [32]:

$$
\Xi \mathrm{MeOH}+\mathrm{Mz}^{+} \rightarrow \mathrm{MeOM}(\mathrm{z}-1)+\mathrm{H}^{+}
$$

In order to explain the high positive loadings found between Mn and As concentrations in the groundwater of the Trifilia (Western Greece) karst aquifer, Panagopoulos and 
Panagiotaras 2011 [44] rewritten equation 5 as equation 6 in the case of As and Mnoxides/hydroxides phases:

$$
\Xi \mathrm{Mn} \mathrm{OH}+\mathrm{As}^{3+} \rightarrow \Xi \mathrm{MnOAs}^{2+}+\mathrm{H}^{+}
$$

In the case of oxidative weathering and dissolution of arsenic-containing minerals, they are primarily account for dissolved inorganic $\mathrm{As}(\mathrm{V})$ and $\mathrm{As}(\mathrm{III})$ ions in aquifers [10; 12]. This complex process can involve biological, chemical and electrochemical reactions and hydrodynamic factors. Subsequent mobility of the arsenic in groundwater depends on adsorption by mineral phases in soils and bedrocks, especially iron (III) hydroxides which have a high affinity for $\mathrm{As}(\mathrm{V})[14 ; 45 ; 46]$. The processes can be depicted as in the following figure 3 [45]:



(Bacterial catalytic oxidation)

Fig. 3. Oxidative weathering and dissolution of arsenic-containing minerals in aquifers involving bacterial catalytic oxidation [45].

To some extent, the process can be regarded as the oxidation of arsenopyrite by amorphous ferric hydroxide. The oxy-anions of arsenic formed are quickly immobilized by the Fe(III) hydroxides due to equation 7 [45]:

$$
\mathrm{FeAsS}+\mathrm{Fe}(\mathrm{OH})_{3} \rightarrow\left[\mathrm{Fe}_{x}{ }^{2+} \mathrm{Fe}^{3+}(\mathrm{OH})_{3}{ }^{\mathrm{x}}\right]\left(\mathrm{AsO}_{4}, \mathrm{AsO}_{3}\right)_{\mathrm{x}}+\text { Products }
$$

where $x$ is less than one and the arsenic is adsorbed or co-precipitated with the ferrosoferric hydroxides. The reaction is sustained by the shuttling of electrons between the oxidizing arsenopyrite surface and the ferric hydroxide, along chemical and biological pathways [45].

In other cases, arsenic correlated with $\mathrm{HCO}_{3}{ }^{-}[15 ; 16 ; 41 ; 42]$. The correlation with $\mathrm{HCO}_{3}{ }^{-}$was determined to be due to reductive dissolution of iron oxides-hydroxides coupled with oxidation of abundant organic matter in the sediments.

Significantly greater concentrations of $\mathrm{HCO}_{3}{ }^{-}$are likely due to $\mathrm{CO}_{2}{ }^{3-}$ as a result of Organic Matter (OM) oxidation during reductive dissolution of ferric oxides-hydroxides. 
The cycling of arsenic in such a case can be described by equations 8 and 9. Equation 8 delineates the adsorption of As onto the surface of Fe-oxides/hydroxides solid phases and introduced by Stumm and Morgan 1996 (equation 5) [32]. Equation 9 has been described by Nickson et al. 2000 [16] who proposed the release of As by the reductive dissolution of ferric oxides-hydroxides.

$$
\begin{gathered}
\Xi \mathrm{FeOH}+\mathrm{As}^{3+} \rightarrow \Xi \mathrm{FeOAs}^{2+}+\mathrm{H}^{+} \\
4 \mathrm{FeOOH}+\mathrm{CH}_{2} \mathrm{O}+7 \mathrm{H}_{2} \mathrm{CO}_{3} \rightarrow 4 \mathrm{Fe}^{2+}+8 \mathrm{HCO}_{3}-+6 \mathrm{H}_{2} \mathrm{O}
\end{gathered}
$$

The vital role that microorganisms play in the release and/or immobilization of arsenic can be evidenced via the presence of significant amounts of organic matter and of viable populations of bacteria regarding arsenic reduction. [45].

Organic ligands can be bound with arsenic in solution and also decrease the amount of adsorption of arsenic coupled with reductive iron dissolution [47].

Due to the unstable nature of the arsenic species it might be rendered as difficult to treat wastes with unstable toxicity and mobility under certain environmental conditions. For long-term disposal and treatment purposes it is required that we understand the element's chemistry and the environment of its disposal.

Current research has expressed an increasing interest and has also shifted its focus on studies regarding the speciation of arsenic in both environmental and biological samples. A limitation is being posed alongside this research path and this is the low level of arsenic species in real samples. This implies that problems highly correlated with the element's speciation remain unresolved. Examples of these problems among others include: species instability during sampling, sample and storage treatment, partially complete recovery of all species, matrix interferences, lack of appropriate certified reference materials and of sensitive analytical methods [6; 17].

Analytical procedures through continuous development calls for an up-to-date knowledge of the recent publications for the purpose of coping successfully with these problems. Detection limits are provided for the majority of the methods. This takes place for the purpose of comparison affordability and for judging the possible applicability. Various researchers have approached these studies in a variety of ways that can lead to knowledge. Knowledge is the main determinant for the understanding of the environmental cycle regarding this element. Furthermore, it facilitates the understanding of its physiological and toxicological behaviour in the living organisms $[6 ; 17 ; 45]$.

Arsenic does not form any complexes with simple anions like $\mathrm{Cl}^{-}$and $\mathrm{SO}_{4}{ }^{2-}$ as is the case with the cationic metals since it forms anions in solution. The behaviour of anionic arsenic resembles the behaviour of ligands in water. It furthermore forms bonds with nitrogen, carbon and the organic sulphur. As (III) has been found to react with sulphur and sulphydryl groups i.e. cystine, organic dithiols, proteins, enzymes. It has not been found to react with amine groups or with organics with reduced nitrogen constituents [17].

On the opposite side, As (V) has been found to react with amines (reduced nitrogen groups but not with groups of sulphydryl. Organoarsenicals in both trivalent and pentavalent forms can be formed by carbon. The complexation of arsenic III and V by dissolved organic 
matter in natural environments has been found to prevent sorption and co-precipitation with both solid-phase organics and inorganics. Thus, it increases arsenic's mobility in both the soil and aquatic systems $[48 ; 49]$.

It is possible for arsenic inorganic compounds to be methylated by bacteria, fungi, and yeasts to organic compounds. As such, it can be methylated into monomethylarsonic acid (MMA), dimethylarsinic acid (DMA), and gaseous derivatives of arsine.

The Bangladeshi samples were the ones that provided the correlation of arsenic with $\mathrm{NH}_{3}-$ $\mathrm{N}$, methane $\left(\mathrm{CH}_{4}\right)$, Dissolved Organic Carbon (DOC), and Ca [41; 43]. The presence of Dissolved Oxygen (DO) or nitrates did not provide any evidence on the existence of arsenic $[15 ; 16]$. According to various observations arsenic and $\mathrm{SO}_{4}{ }^{2-}$ tend to be mutually exclusive [41; 50]. Further on this path, Dowling et al. (2002) observed that $\mathrm{SO}_{4}{ }^{2-}$ was absent from the samples received and observed, as well as, that arsenic was found to correlate with $\mathrm{NH}_{3}-\mathrm{N}$ and Total Organic Carbon (TOC) [43]. Various parts of the Mahomet Aquifer have provided evidence of methane existence. According to Meents (1960), $\mathrm{CH}_{4}$ has been derived from the degradation of organic matter in the Sankoty sand found in the Mahomet Aquifer, Illinois [51]. He further reported buried soils, peats, and organic-rich silts associated with interglacial stages, especially the Sangamon soil, which overly the Mahomet aquifer as being additional $\mathrm{CH}_{4}$ sources [30].

\section{Conclusions}

The distribution of arsenic species and chemistry in aquatic environments is a function of redox reactions, adsorption-desorption processes and dissolution of solid phases. In such a complex system the activity of bacteria must be considered in order to evaluate possible arsenic dissolution mechanisms. The concentrations of several ions and water quality parameters, and the relations between arsenic occurrence and other chemical components must be examined in order to better understand the correlation between them and gain the overall knowledge of arsenic geochemistry in groundwater system.

\section{References}

[1] U.S. EPA. Arsenic Treatment Technologies for Soil, Waste, and Water. EPA-542-R-02 004. September 2002. http://clu in.org/download/remed/542r02004/arsenic_report.pdf .

[2] U.S. EPA. National Primary Drinking Water Regulations; Arsenic and Clarifications to Compliance and New Source Contaminants Monitoring; Final Rule. Federal Register, Volume 66, Number 14, p. 6975-7066. January 22, 2001. http:/ / www.epa.gov/sbrefa/documents/pnl14f.pdf.

[3] Welch, A.H., Westjohn, D.B., Helsel, D.R., Wanty, R.B., 2000. Arsenic in ground water of the United States: occurrence and geochemistry. Ground Water 38, 589-604.

[4] Edmunds, W.M., Cook, J.M., Kinniburgh, D.G., Miles, D.L., Trafford, J.M., 1989. Traceelement Occurrence in British Groundwaters. Res. Report SD/89/3, British Geological Survey, Keyworth.

[5] Smedley P. L. and Kinniburgh D. G. (2002) A review of the source, behaviour and distribution of arsenic in natural waters. Applied Geochemistry 17, 517-568. 
[6] U.S. EPA-542-R-02-004. Arsenic Treatment Technologies for Soil, Waste, and Water. September 2002. www.epa.gov/tioclu-in.org/arsenic.

[7] U.S. EPA. National Primary Drinking Water Regulations; Arsenic and Clarifications to Compliance and New Source Contaminants Monitoring; Proposed Rule. Federal Register, Vol 65, Number 121, p. 38888. June 22, 2000. http://www.epa.gov/safewater/ars/arsenic.pdf..

[8] Fleischer, M., 1983. Glossary of Mineral Species. The mineral record Inc, Tucson, Arizona..

[9] Boyle, D.R., Turner, R.J.W., Hall, G.E.M., 1998. Anomalous arsenic concentrations in groundwaters of an island community, Bowen island, British Columbia. Environ. Geochem. Health 20, 199-212.

[10] Smedley, P.L., Edmunds, W.M., Pelig-Ba, K.B., 1996. Mobility of arsenic in groundwater in the Obuasi gold-mining area Ghana: some implications for human health. In: Appleton, J.D., Fuge, R., McCall, G.J.H. (Eds.), Environmental Geochemistry and Health, vol. 113. Geological Society Special Publication, London, pp. 163-181.

[11] Williams, M., Fordyce, F., Paijitprapapon, A., Charoenchaisri, P., 1996. Arsenic contamination in surface drainage and groundwater in part of the southeast Asian tin belt, Nakhon Si Thammarat Province, southern Thailand. Environ. Geol. 27, 1633.

[12] Chowdhury, T.R., Basu, G.K., Mandal, B.K., Biswas, B.K., Samanta, G., Chowdhury, U.K., Chanda, C.R., Lodh, D., Roy, S.L., Saha, K.C., Roy, S., Kabir, S., Quamruzzaman, Q., Chakraborti, D., 1999. Arsenic poisoning in the Ganges delta. Nature 401, 545-546.

[13] Mandal, B.K., Chowdhury, T.R., Samanta, G., Mukherjee, D.P., Chanda, C.R., Saha, K.C., Chakraborti, D., 1998. Impact of safe water for drinking and cooking on five arsenic-affected families for 2 years in West Bengal, India. Sci. Total Environ. 218, 185-201.

[14] Acharyya, S.K., Chakraborty, P., Lahiri, S., Raymahashay, B.C., Guha, S., Bhowmik, A., 1999. Arsenic poisoning in the Ganges delta. Nature 401, 545.

[15] Nickson, R., McArthur, J., Burgess, W., Ahmed, K.M., Ravenscroft, P., Rahman, M., 1998. Arsenic poisoning of Bangladesh groundwater. Nature 395, 338.

[16] Nickson, R.T., McArthur, J.M., Ravenscroft, P., Burgess, W.G., Ahmed, K.M., 2000. Mechanism of arsenic release to groundwater, Bangladesh and West Bengal. Appl. Geochem. 15, 403-413.

[17] M. Kumaresan and P. Riyazuddin (2001). Overview of speciation chemistry of arsenic. Current Science, Vol. 80, No. 7, 10, 837-846.

[18] The Agency for Toxic Substances and Disease Registry (ATSDR): ToxFAQs TM for Arsenic (12). July, 2001. http://www.atsdr.cdc.gov/tfacts2.html.

[19] Kirk-Othmer. "Arsenic and Arsenic Alloys." The Kirk-Othemer Encyclopedia of Chemical Technology, Volume 3. John Wiley and Sons, New York. 1992.

[20] National Research Council. Arsenic in Drinking Water. Washington, D.C. National Academy Press. 1999. http://www.nap.edu/catalog/6444.html.

[21] Korte, N., 1991. Naturally occurring arsenic in groundwaters of the Midwestern United States. Environ. Geol. Water Sci. 18, 137-141.

[22] Matisoff, G., Khourey, C.J., Hall, J.F., Varnes, A.W., Strain, W.H., 1982. The nature and source of arsenic in northeastern Ohio ground water. Ground Water 20, 446-456. 
[23] Nimick, D.A., 1998. Arsenic hydrogeochemistry in an irrigated river valley-a reevaluation. Ground Water 36, 743-753.

[24] Das, D., Samanta, G., Mandal, B.K., Chowdhury, T.R., Chanda, C.R., Chowdhury, P.P., Basu, G.K., Chakraborti, D., 1996. Arsenic in groundwater in six districts of West Bengal, India. Environ. Geochem. Health 18, 5-15.

[25] Welch A. H., Westjohn D. B., Helsel D. R., and Wanty R. B. (2000) Arsenic in ground water of the United States: Occurrence and geochemistry [Review]. Ground Water 38(4), 589-604.

[26] Schreiber M. E., Simo J. A., and Freiberg P. G. (2000) Stratigraphic and geochemical controls on naturally occurring arsenic in groundwater, eastern Wisconsin, USA. Hydrogeology Journal 8(2), 161-176.

[27] Scow, K., Byrne, M., Goyer, M., Nelken, L., Perwak, J., Wood, M. and Young, S., Final Draft Report to the US Environmental Protection Agency, EPA Contract 68-016160, Monitoring and Data Support, Office of Water Regulations and Standards, Washington, DC, 1981.

[28] Rai, D., Zachara, J., Schwabe, A., Schmidt, R., Girvin, D. and Rogers, J., Report, EA-3356 to EPRI by Pacific Northwest Laboratories, Battelle Institute, Richland, Wash, 1984.

[29] Vance, David B. "Arsenic - Chemical Behavior and Treatment". October, 2001. http:/ / 2the4.net/arsenicart.htm.

[30] Thomas R. Holm, Walton R. Kelly, Steven D. Wilson, George S. Roadcap, Jonathan L. Talbott, John W. Scott, (2004). Arsenic Geochemistry and Distribution in the Mahomet Aquifer, Illinois. Illinois Waste Management and Research Center. Division of the Illinois Department of Natural Resources. http://www.wmrc.uiuc.edu/main_sections/info_services/library_docs/RR/RR107.pdf.

[31] Nordstrom D. K. and Archer D. G. (2003) Arsenic thermodynamic data and environmental geochemistry. In Arsenic in Ground Water (ed. A. H. Welch and K. G. Stollenwerk), pp. 1-25. Kluwer.

[32] Stumm W. and Morgan J. J. (1996) Aquatic Chemistry: Chemical Equilibria and Rates in Natural Waters, 3rd ed. Wiley.

[33] Armienta M. A., Villasenor G., Rodriguez R., Ongley L. K., and Mango H. (2001) The role of arsenic-bearing rocks in groundwater pollution at Zimapan Valley, Mexico. Environmental Geology 40(4-5), 571-581.

[34] Bottomley D. J. (1984) Origins of some arseniferous groundwaters in Nova Scotia and New Brunswick, Canada. Journal of Hydrology 69(1-4), 223-257.

[35] Planer-Friedrich B., Armienta M. A., and Merkel B. J. (2001) Origin of arsenic in the groundwater of the Rioverde basin, Mexico. Environmental Geology 40(10), 12901298.

[36] Robertson F. N. (1989) Arsenic in ground-water under oxidizing conditions, south-west United States. Envrion. Geochem. Health 11(3-4), 171-185.

[37] Smedley P. L. (1996) Arsenic in rural groundwater in Ghana. J. African Earth Sciences 22(4), 459-470.

[38] Welch A. H., Lico M. S., and Hughes J. L. (1988) Arsenic in ground water of the western United States. Ground Water 26, 333-347.

[39] Kim M. J., Nriagu J., and Haack S. (2000) Carbonate ions and arsenic dissolution by groundwater. Environmental Science \& Technology 34(15), 3094-3100. 
[40] Lee J. S. and Nriagu J. O. (2003) Arsenic carbonate complexes in aqueous systems. In Biogeochemistry of environmentally important trace metals (ed. Y. Cai and O. C. Braids), pp. 33-41. American Chemical Society.

[41] Harvey C. F., Swartz C. H., Badruzzaman A. B. M., Keon-Blute N., Yu W., Ali M. A., Jay J., Beckie R., Niedan V., Brabander D., Oates P. M., Ashfaque K. N., Islam S., Hemond H. F., and Ahmed M. F. (2002) Arsenic mobility and groundwater extraction in Bangladesh. Science 298(5598), 1602-1606.

[42] McArthur J. M., Ravenscroft P., Safiulla S., and Thirlwall M. F. (2001) Arsenic in groundwater: Testing pollution mechanisms for sedimentary aquifers in Bangladesh. Water Resources Research 37(1), 109-117.

[43] Dowling C. B., Poreda R. J., Basu A. R., Peters S. L., and Aggarwal P. K. (2002) Geochemical study of arsenic release mechanisms in the Bengal Basin groundwater - art. no. 1173. Water Resources Research 38(9), 12-1 - 12-18.

[44] G. Panagopoulos and D. Panagiotaras (2011). Understanding the extent of geochemical and hydrochemical processes in coastal karst aquifers through ion chemistry and multivariate statistical analysis. Fresenius Environmental Bulletin, volume 20, No 12a, 3270-3285.

[45] Myoung-Jin Kim, Jerome Nriagu, Sheridan Haack (2002). Arsenic species and chemistry in groundwater of southeast Michigan. Environmental Pollution 120, 379-390.

[46] Welch, A.H., Lico, M.S., 1998. Factors controlling As and U in shallow ground water, southern Carson Desert, Nevada. Appl. Geochem. 13, 521-539.

[47] Redman A. D., Macalady D. L., and Ahmann D. (2002) Natural organic matter affects arsenic speciation and sorption onto hematite. Environmental Science \& Technology 36(13), 2889-2896.

[48] Callahan, M. et al. Report, EPA-440/4-79-029a, EPA Contracts 68-01-3852 and 68-013867, Office of Water Planning and Standards, US Environmental Protection Agency, Washington, DC, 1979.

[49] Ferguson, J. F. and Davis, J., (1972). A review of the arsenic cycles in natural waters. J., Water Res., 6, 1259-1274.

[50] Ravenscroft P., McArthur J. M., and Hoque B. A. (2001) Geochemical and Palaeohydrological Controls on Pollution of Groundwater by Arsenic. Arsenic Exposure and Health Effects IV, 1-20.

[51] Meents W. F. (1960) Glacial-Drift Gas in Illinois, pp. 58. Illinois State Geological Survey. 




\author{
Geochemistry - Earth's System Processes \\ Edited by Dr. Dionisios Panagiotaras
}

ISBN 978-953-51-0586-2

Hard cover, 500 pages

Publisher InTech

Published online 02, May, 2012

Published in print edition May, 2012

This book brings together the knowledge from a variety of topics within the field of geochemistry. The audience for this book consists of a multitude of scientists such as physicists, geologists, technologists, petroleum engineers, volcanologists, geochemists and government agencies. The topics represented facilitate as establishing a starting point for new ideas and further contributions. An effective management of geological and environmental issues requires the understanding of recent research in minerals, soil, ores, rocks, water, sediments. The use of geostatistical and geochemical methods relies heavily on the extraction of this book. The research presented was carried out by experts and is therefore highly recommended to scientists, underand post-graduate students who want to gain knowledge about the recent developments in geochemistry and benefit from an enhanced understanding of the dynamics of the earth's system processes.

\title{
How to reference
}

In order to correctly reference this scholarly work, feel free to copy and paste the following:

Dionisios Panagiotaras, George Panagopoulos, Dimitrios Papoulis and Pavlos Avramidis (2012). Arsenic Geochemistry in Groundwater System, Geochemistry - Earth's System Processes, Dr. Dionisios Panagiotaras (Ed.), ISBN: 978-953-51-0586-2, InTech, Available from: http://www.intechopen.com/books/geochemistryearth-s-system-processes/arsenic-geochemistry-in-groundwater-system

\section{INTECH}

open science | open minds

\author{
InTech Europe \\ University Campus STeP Ri \\ Slavka Krautzeka 83/A \\ 51000 Rijeka, Croatia \\ Phone: +385 (51) 770447 \\ Fax: +385 (51) 686166 \\ www.intechopen.com
}

\author{
InTech China \\ Unit 405, Office Block, Hotel Equatorial Shanghai \\ No.65, Yan An Road (West), Shanghai, 200040, China \\ 中国上海市延安西路65号上海国际贵都大饭店办公楼 405 单元 \\ Phone: +86-21-62489820 \\ Fax: +86-21-62489821
}


(C) 2012 The Author(s). Licensee IntechOpen. This is an open access article distributed under the terms of the Creative Commons Attribution 3.0 License, which permits unrestricted use, distribution, and reproduction in any medium, provided the original work is properly cited. 